Dhaka Univ. J. Biol. Sci. 28(2): 177-185, 2019 (July)

\title{
PERFORMANCE OF WASTE CONCERN ORGANIC FERTILIZER ON THE GROWTH AND YIELD OF T. AMAN RICE IN TWO AEZs OF BANGLADESH
}

\author{
M. R. ISLAM ${ }^{1}$, P. K. SAHA ${ }^{1}$, S. K. ZAMAN ${ }^{1}$ AND M. J. UdDIN* \\ Department of Soil, Water and Environment, University of Dhaka, Dhaka-1000, Bangladesh
}

Key words: Waste concern, Organic fertilizer, Growth and yield, T. aman rice

\begin{abstract}
Two field experiments were conducted in two AEZs of Bangladesh viz. AEZ 28 and AEZ 3 to test the performance of waste concern organic fertilizer (WCOF) on the growth and yield of T. aman rice. The test sites were selected in the BRRI farm, Gazipur under AEZ 28 and BRRI farm Rangpur under AEZ 3. The experiments were done by using six treatments where $\mathrm{T}_{1}=$ Absolute control, $\mathrm{T}_{2}=$ NPKS @ 80-35-40-10 kg ha, $\mathrm{T}_{3}=\mathrm{T}_{2}+1$ t WCOF $/$ ha, $\mathrm{T}_{4}=75 \%$ of $\mathrm{T}_{2}+1$ t WCOF ha, $\mathrm{T}_{5}=50 \%$ of $\mathrm{T}_{2}+2 \mathrm{t}$ WCOF/ha and $\mathrm{T}_{6}=2 \mathrm{t}$ WCOF/ha. The application of WCOF in combination with chemical fertilizer significantly increased plant height, panicle number, grain and straw yields of T. aman rice over control in both AEZs. It was observed that the application of WCOF @ $1 \mathrm{t} / \mathrm{ha}+75 \%$ of T2 (NPKS @ 80-35-40-10 $\mathrm{kg}$ /ha) produced higher yields. The study revealed that the treatments $\mathrm{T}_{4}$ and $\mathrm{T}_{5}$ may be the most economically viable fertilizer management packages for $\mathrm{T}$. aman rice cultivation in AEZ 28 while the treatment $\mathrm{T}_{4}$ may be recommended for AEZ 3.
\end{abstract}

\section{Introduction}

Global food production increased by 70\% from 1970 to 1995 in developing countries, largely due to the green revolution technologies which use high-yielding inputs such as high-yielding varieties (HYVs), irrigation, chemical fertilizers and synthetic pesticides ${ }^{(1,2)}$. Though the green revolution technologies have increased crop yields and produced more food to meet the caloric requirements of the global population ${ }^{(3)}$. These technological development aggravates the situation with more environmental hazards, such as increased soil erosion, surface and groundwater contamination, greenhouse gas emissions, increased pest resistance and reduced biodiversity ${ }^{(4,5)}$. These concerns suggest that more sustainable methods of food production are essential to meet the food requirements of ever-increasing population but at the same time sustaining natural resource base by avoiding land degradation and mitigating climate change( ${ }^{(6)}$. Over the last 2 - 3 decades, organic agriculture has been advocated as an alternative form of farming to produce food sustainably by reducing the impact on agriculture and the environment $(7,8)$.

*Author for correspondence: <mjuddin66@yahoo.com>. ${ }^{1}$ Bangladesh Rice Research Institute (BRRI), Gazipur, Bangladesh. 
As a result of intensive agriculture, a significant amount of SOC stock has been lost from agricultural soils. This loss of SOC stock was approximately 60 and $75 \%$ of total SOC storage at the tropical ecosystems ${ }^{(9,10)}$. In South Asia, soil C in the agricultural soils ranged from 8 to $10 \mathrm{~g} / \mathrm{kg}$, a low level resulting from nutrient depletion, intensive tillage, erosion, unbalanced fertilization, and residue removal (11). In Bangladesh alone about 16.2 Mg C ha was removed from a soil between 1967 and 1995 due to intensive agricultural practices $^{(11)}$. A considerable decrease in crop production in long-term research sites across the South Asia also suggests a loss of SOC in agricultural soils in this region (12, 13, 14). Depletion of inherent capacity of soil in sustaining crop production is the great challenge for improving food security and sustainability of agriculture ${ }^{(15)}$. Nutrient mining in Bangladesh soils has been noted as a serious threat for crop production. A study shows that a total loss of 1.25 million tons of $\mathrm{N}, \mathrm{P}$ and $\mathrm{K}$ from the agricultural soils of Bangladesh every year where loss of $\mathrm{K}$ alone is the highest and has been reported to be more than one million tons per year(16). In Bangladesh, nutrient depletion ( $\mathrm{kg}$ /ha/year) in arable farming is seen for $\mathrm{N}(16), \mathrm{P}(1)$ and $\mathrm{K}$ (26) where K depletion rate is highest ${ }^{(17)}$. Global soil nutrient depletion is related to yield reduction and the depletion rate is at an average rate $(\mathrm{kg}$ /ha/year) of $\mathrm{N}$ (18.7), $\mathrm{P}(5.1)$, and $\mathrm{K}$ (38.8) where $\mathrm{K}$ depletion rate is also highest ${ }^{18)}$. Considering the above facts, an experiment was undertaken to evaluate the performance of WCOF on the growth and yield of T. aman rice.

\section{Materials and Methods}

The waste concern organic fertilizer (WCOF) developed by waste concern Jaiba Sar Company Bangladesh Ltd. is a nutrient enriched organic fertilizer. Physically, it is dark grayish brown in color, soft bodied granular size and odorless. Chemically, it contains $23 \%$ organic $\mathrm{C}, 2 \%$ total $\mathrm{N}, 1.7 \% \mathrm{P}, 2.6 \% \mathrm{~K}, 0.25 \% \mathrm{~S}, 0.04 \% \mathrm{Zn}$ and $16.3 \%$ moisture. The content of heavy metals is less than permissible level. Two field experiments were conducted at BRRI Farm, Gazipur and Rangpur during T. aman season, 2008. Soil samples were air-dried, ground and passed through a $2 \mathrm{~mm}$ sieve and preserved for the analyses of initial soil characteristics (Table 1). Organic carbon in soil was determined by the wet oxidation method ${ }^{(19)}$. Soil textural class was determined by hydrometer $\operatorname{method}^{(20)}$. Soil $\mathrm{pH}$ was measured at a soil-water ratio $1: 2.5$ using Hanna $212 \mathrm{pH}$ meter.

Available sulphur was extracted with calcium di-hydrogen phosphate and was determined by turbid metrically ${ }^{(21)}$. Zinc was extracted using DTPA(22) and was determined by using an atomic absorption spectrophotometer 7000 manufactured by Shimadzu, Japan. Ammonium acetate extractable $\mathrm{K}^{(23)}$ was determined by flame photometer 410 manufactured by Sherwood, Japan. Total nitrogen was determined by Kjeldahl's method as described ${ }^{(24)}$. Available phosphorus from acid soil was extracted using the Bray 2 method $^{(25)}$. As per soil chemical datasets, the study sites belongs to strongly acidic to slightly acidic reaction with very low organic carbon contents ${ }^{26)}$. 
The study sites bear low nutrients capacities specifically K deficient soils. A study shows that the lowest $\mathrm{K}$ was found in the rice based farming system where $\mathrm{K}$ mining is widespread ${ }^{(27)}$.

Six treatment combinations were tested: $\mathrm{T}_{1}=$ Absolute control (Native nutrients), $\mathrm{T}_{2}=$ NPKS @ 80-35-40-10 kg/ha, $\mathrm{T}_{3}=\mathrm{T}_{2}+1 \mathrm{t} \mathrm{WCOF/ha,} \mathrm{T}_{4}=75 \%$ of $\mathrm{T}_{2}+1 \mathrm{t} \mathrm{WCOF} / \mathrm{ha}, \mathrm{T}_{4}=50 \%$ of $\mathrm{T}_{2}+2 \mathrm{t} \mathrm{WCOF}$ ha and $\mathrm{T}_{6}=2 \mathrm{t}$ WCOF $/$ ha. The experiments were laid out in randomized complete block design with four replications. The sources of nutrients were urea, triple superphosphate (TSP), muriate of potash (MoP) and gypsum, respectively. All TSP, MoP, gypsum and WCOF were applied at the time of final land preparation. Urea was applied into three equal splits: $1 \beta$ rd as basal, $1 \beta$ rd at early tillering stage and the remaining $1 \beta^{\text {rd }}$ at $5-7$ days before panicle initiation stage. BRRI dhan 31 and BRRI dhan 46 were used as a test crop at Gazipur and Rangpur sites, respectively. Thirty five days old 2-3 seedlings hill were transplanted with $20 \mathrm{~cm} \times 20 \mathrm{~cm}$ spacing. Necessary intercultural operations were done as required. At maturity, the crop was harvested from $5 \mathrm{~m}^{2}$ area at the centre of each plot and grain yield was adjusted to $14 \%$ moisture. The plant height, tiller no, panicle no, grain and straw yields were recorded. The datasets were analyzed following IRRISTAT version 4.1(28). Finally economic analyses were made for added return, net return, and marginal benefit cost ratio (MBCR) ${ }^{(29)}$.

Table 1. Initial soil characteristics of the experimental plots of BRRI farm.

\begin{tabular}{lcc}
\hline Parameters & $\begin{array}{c}\text { BRRI Farm, } \\
\text { Gazipur }\end{array}$ & $\begin{array}{c}\text { BRRI Farm, } \\
\text { Rangpur }\end{array}$ \\
\hline Texture & Clay-loam & Sandy-loam \\
$\mathrm{pH}(1: 2.5)$ & 6.1 & 5.1 \\
Organic C $(\%)$ & 1.2 & 1.1 \\
Total N $(\%)$ & 0.07 & 0.08 \\
Available P $(\mathrm{mg} / \mathrm{kg})$ & 10.1 & 25.0 \\
Exchangeable K $(\mathrm{cmol} / \mathrm{kg})$ & 0.17 & 0.13 \\
Available S $(\mathrm{mg} / \mathrm{kg})$ & 6.1 & 3.9 \\
Available $\mathrm{Zn}(\mathrm{mg} / \mathrm{kg})$ & 2.8 & 1.3 \\
\hline
\end{tabular}

\section{Results and Discussion}

Application of WCOF in combination with chemical fertilizer significantly increased plant height, panicle number, grain and straw yield of BRRI dhan31 and BRRI dhan46 over control at both Gazipur and Rangpur sites (Tables 2 and 3). In BRRI Farm, Gazipur, the treatments $T_{2}, T_{3}, T_{4}$ and $T_{5}$ produced statistically identical plant height and panicle number $/ \mathrm{m}^{2}$, which showed higher vegetative growth than that of treatment $\mathrm{T}_{6}$ and $\mathrm{T}_{1}$ (Table 2). The highest tiller number $/ \mathrm{m}^{2}$ (268) was obtained with treatment $\mathrm{T}_{3}$ followed by $T_{5}$ (254). In BRRI Farm, Rangpur, the highest plant height was found in treatment $T_{3}$ 
$(126.6 \mathrm{~cm})$ followed by $\mathrm{T}_{4}(123.7 \mathrm{~cm})$ and $\mathrm{T}_{2}(123.2 \mathrm{~cm})$. It was significantly higher than that of $T_{6}$ and $T_{1}$. The treatment $T_{3}$ produced the highest number of panicle $/ \mathrm{m}^{2}$ (225). It was also significantly higher than that of other treatments (Table 2).

Table 2. Effects of waste concern organic fertilizer on plant height $(\mathrm{cm})$, tiller and panicle number in T. aman season at BRRI farms.

\begin{tabular}{|c|c|c|c|c|c|c|}
\hline \multirow[b]{2}{*}{ Treatments } & \multicolumn{2}{|c|}{ Plant height $(\mathrm{cm})$} & \multicolumn{2}{|c|}{ Tiller $/ \mathrm{m}^{2}$} & \multicolumn{2}{|c|}{ Panicle $/ \mathrm{m}^{2}$} \\
\hline & $\begin{array}{l}\text { Gazipur } \\
\text { site }\end{array}$ & $\begin{array}{l}\text { Rangpur } \\
\text { site }\end{array}$ & $\begin{array}{l}\text { Gazipur } \\
\text { site }\end{array}$ & $\begin{array}{l}\text { Rangpur } \\
\text { site }\end{array}$ & $\begin{array}{l}\text { Gazipur } \\
\text { site }\end{array}$ & $\begin{array}{l}\text { Rangpur } \\
\text { Site }\end{array}$ \\
\hline $\mathrm{T}_{1}$ & $92.1 \mathrm{~d}$ & $112.7 \mathrm{~b}$ & $203 c$ & 208 & $192 b$ & $188 \mathrm{bc}$ \\
\hline $\mathrm{T}_{2}$ & $105.2 \mathrm{ab}$ & $123.2 \mathrm{a}$ & $246 b$ & 247 & $234 a$ & $211 \mathrm{ab}$ \\
\hline $\mathrm{T}_{3}$ & $107.0 \mathrm{a}$ & $126.6 \mathrm{a}$ & $268 \mathrm{a}$ & 252 & $251 \mathrm{a}$ & $225 a$ \\
\hline $\mathrm{T}_{4}$ & $107.6 \mathrm{a}$ & $123.7 \mathrm{a}$ & $251 b$ & 240 & $235 a$ & $210 \mathrm{ab}$ \\
\hline $\mathrm{T}_{5}$ & $101.4 \mathrm{bc}$ & $119.2 \mathrm{ab}$ & $254 \mathrm{ab}$ & 237 & $243 a$ & $205 \mathrm{abc}$ \\
\hline $\mathrm{T}_{6}$ & $96.5 c$ & $113.4 \mathrm{~b}$ & $207 c$ & 204 & $196 b$ & $176 c$ \\
\hline $\operatorname{LSD}_{0.05}$ & 5.3 & 7.9 & 15 & NS & 17 & 31 \\
\hline CV (\%) & 3.4 & 4.4 & 4.1 & 11 & 4.9 & 10 \\
\hline
\end{tabular}

Means with same letter in a column are not significantly different at 5\% level of probability.

Applied fertilizer significantly increased the grain yield of rice at both locations (Table 3). In BRRI Farm, Gazipur, the highest grain yield of $3.66 \mathrm{t}$ ha was obtained with the treatment $T_{5}$ followed by the treatments $T_{4}$ and $T_{2}$. These treatments were statistically identical and showed higher vegetative growth than $T_{6}$ and $T_{1}$. Per cent grain yield increased over control treatment $\mathrm{T}_{3}$ produced the significantly highest straw yield of 6.39 tha (Table 3).

In BRRI Farm, Rangpur the highest grain yield of $5.17 \mathrm{t}$ ha was obtained with the treatment $\mathrm{T}_{3}$, which was statistically identical with that of $\mathrm{T}_{4}$. The yield increased by 16 $20 \%$ over the control plot. All the treated plots $\left(\mathrm{T}_{2}-\mathrm{T}_{6}\right)$ produced statistically identical straw yield (Table 3). From the above results, it is observed that the application of WCOF @ $1 \mathrm{t}$ ha $+75 \%$ of $\mathrm{T}_{2}$ (NPKS @ 80-35-40-10 kg /ha) performed with higher yields.

The estimated total variable cost (TVC), gross return, for added return, net return and marginal benefit cost ratio (MBCR) are presented in Table 4. Economic analysis was done considering the fertilizer cost, fertilizer application cost and labor cost for the additional products. At Gazipur site, the application of fertilizer increased the gross and net return with all the treatments (Table $4 \mathrm{~b}$ ). The gross return from the control plot was only about Tk. 56,740.00 per ha and the application of fertilizer increased the gross return, where Tk. 66,680.00 per ha by the treatment $T_{6}$ and Tk. 77,000.00 per ha by the treatment $T_{5}$. The highest net-return of Tk. 58,644.00 per ha was obtained with the treatment $\mathrm{T}_{6}$ followed by treatment $\mathrm{T}_{4}$ (Tk. 58,522.00 per ha). The highest added-return of 
Tk. 20,260.00 per ha was obtained with the treatment $\mathrm{T}_{5}$ followed by treatment $\mathrm{T}_{4}$ (Tk. 19,660.00). The highest MBCR was obtained with the treatment $T_{6}$ (1.24) followed by treatment $T_{5}$ (1.10) and treatment $T_{4}(1.00)$. The treatments $T_{4}$ and $T_{5}$ may be the most economically viable fertilizer management packages for $\mathrm{T}$. aman rice cultivation at BRRI Farm, Gazipur under AEZ 28.

Table 3. Effects of waste concern organic fertilizer on grain and straw yield $(t / h a)$ in $T$. aman season at BRRI farms.

\begin{tabular}{|c|c|c|c|c|c|c|}
\hline \multirow[t]{2}{*}{ Treatment } & \multicolumn{2}{|c|}{$\begin{array}{l}\text { Grain yield } \\
\text { (t/ha) }\end{array}$} & \multicolumn{2}{|c|}{$\begin{array}{l}\text { Straw yield } \\
(\mathrm{t} / \mathrm{ha})\end{array}$} & \multicolumn{2}{|c|}{$\begin{array}{c}\% \text { grain yield increase } \\
\text { over control }\end{array}$} \\
\hline & $\begin{array}{l}\text { Gazipur } \\
\text { site }\end{array}$ & $\begin{array}{l}\text { Rangpur } \\
\text { site }\end{array}$ & $\begin{array}{l}\text { Gazipur } \\
\text { site }\end{array}$ & $\begin{array}{l}\text { Rangpur } \\
\text { site }\end{array}$ & $\begin{array}{l}\text { Gazipur } \\
\text { site }\end{array}$ & $\begin{array}{l}\text { Rangpur } \\
\text { site }\end{array}$ \\
\hline $\mathrm{T}_{1}$ & $2.71 \mathrm{c}$ & $4.31 \mathrm{c}$ & $3.98 c$ & $4.76 \mathrm{~b}$ & - & - \\
\hline $\mathrm{T}_{2}$ & $3.39 \mathrm{ab}$ & $4.58 \mathrm{bc}$ & $5.38 \mathrm{~b}$ & $5.48 \mathrm{a}$ & 25 & 6 \\
\hline $\mathrm{T}_{3}$ & $3.33 \mathrm{ab}$ & $5.17 \mathrm{a}$ & $6.39 a$ & $5.54 \mathrm{a}$ & 23 & 20 \\
\hline $\mathrm{T}_{4}$ & $3.62 \mathrm{a}$ & $5.00 \mathrm{a}$ & $5.62 \mathrm{~b}$ & $5.44 \mathrm{a}$ & 34 & 16 \\
\hline $\mathrm{T}_{5}$ & $3.66 \mathrm{a}$ & $4.63 \mathrm{abc}$ & $5.56 \mathrm{~b}$ & $5.38 \mathrm{a}$ & 35 & 7 \\
\hline $\mathrm{T}_{6}$ & $3.25 \mathrm{~b}$ & $4.45 \mathrm{bc}$ & $4.09 \mathrm{c}$ & $5.22 \mathrm{a}$ & 20 & 3 \\
\hline $\operatorname{LSD}_{0.05}$ & 0.30 & 0.46 & 0.57 & 0.44 & & \\
\hline CV (\%) & 6.0 & 6.5 & 7.3 & 5.5 & & \\
\hline
\end{tabular}

Means with same letter in a column are not significantly different at $5 \%$ level of probability.

For Rangpur site, similarly the application of fertilizer also increased the gross and added return (Tk/ha) in all the treatments. The gross return from the control plot was only about Tk. 87100.00 per ha and the application of fertilizer increased the gross return Tk. 90540.00 per ha in treatment $\mathrm{T}_{6}$ and Tk. 104140.00 per ha in treatment $\mathrm{T}_{3}$. The highest added-return of Tk. 17040.00 per ha was obtained with the treatment T3 and Tk. 13780.00 per ha by the treatment $\mathrm{T}_{4}$. In terms of MBCR, the treatments $\mathrm{T}_{4}$ and $\mathrm{T}_{3}$ (Table $4 \mathrm{~b}$ ) performed the best among the tested treatment here under AEZ 3.

Soil organic carbon equilibrium means that SOC remains stable when land use, land management, and environmental properties (such as climate, $\mathrm{CO}_{2}$ concentration or nitrogen deposition) do not change either. An equation proposed by (30), which is most appropriate to explain the SOC equilibrium situation in the soils of Bangladesh. The equation is $\mathrm{dc} / \mathrm{dt}=-\mathrm{kC}+\mathrm{A}$. Where, $\mathrm{dc} / \mathrm{dt}=$ rate of SOC change, $\mathrm{k}=$ decomposition constant, $\mathrm{C}=\mathrm{SOC}$ content at a time $\mathrm{t}, \mathrm{A}=$ Accretion constant. The magnitude of $\mathrm{A}$ depends on land use and management. So, the difference between $\mathrm{kC}$ and $\mathrm{A}$ that determines the rate of SOC change. Soil degradation processes decrease SOC and increase the magnitude of decomposition constant k, and, in contrast, soil restorative processes increase SOC and decrease the magnitude of decomposition constant $k^{(31)}$. In 


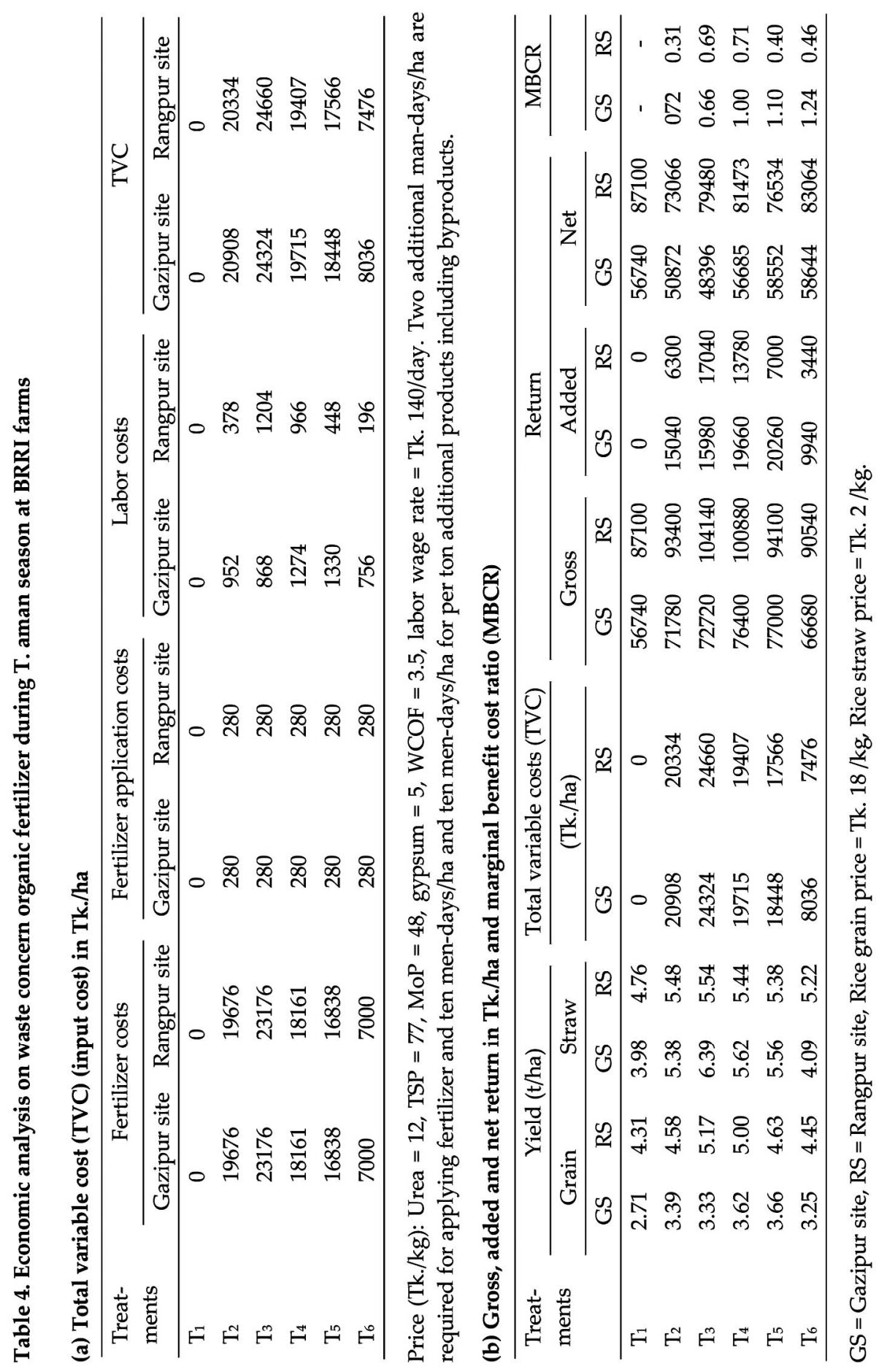


Bangladesh, agricultural land use practices that increase $\mathrm{k}$ due to the effects of continuous cultivation, residue removal, low input subsistence agriculture, excessive tillage etc. The rate of sequestration in the soils of Bangladesh is very slow because of their low SOC contents. If the soil is continuously cultivated (Bangladesh situation), its SOC content declines until an equilibrium level (Ce) is achieved. The magnitude of $\mathrm{Ce}$ depends on the climate, land use and cropping pattern etc. The equation is $\mathrm{C}=\mathrm{Ce}+(\mathrm{Co}-$ Ce) $\mathrm{e}^{-\mathrm{rt}}$ where $\mathrm{C}=\mathrm{SOC}$ constant at time $\mathrm{t}, \mathrm{r}=$ Fraction of $\mathrm{C}$ decomposed /year, $\mathrm{t}=$ Time in years, $\mathrm{Ce}=$ Equilibrium level, $\mathrm{Co}-\mathrm{Ce}=$ Difference in SOC $=$ Gaseous emission into the atmosphere and losses due to soil erosion and leaching as dissolved and particulate carbon. In Bangladesh, SOC has perhaps declined to an equilibrium level, and further decline may not occur unless soil management practices changes further.

Soil organic carbon level is very low in the study sites for crop productivity purposes in comparison of the statement ${ }^{(32)}$ on SOC threshold values in tropical agro-ecosystems. They found that soil organic carbon threshold for sustaining soil quality is widely suggested to be about $2 \%(20 \mathrm{~g} / \mathrm{kg})$ below which deterioration occurs. It is reported that some of the minimum and maximum thresholds of SOC, above or below which the effects of SOC on soil functions are noticeable ${ }^{(33)}$. However, ${ }^{(34)}$ argued that other than defining such maximum values, it is reasonable if minimum SOC levels ( $2 \%$ e.g. $20 \mathrm{~g} / \mathrm{kg}$ ) are established to inform the farming community on levels below which there would be loss of important soil characteristics. SOC at $2 \%$ is considered optimum for soil aggregate stability maintenance while above this level no further increase in productivity or aggregate stability is expected ${ }^{(35)}$. Good soil structure and fertility can be maintained when SOC is $>2 \%$ but most soils in Bangladesh have less than $1 \% \mathrm{SOC}^{(16,24)}$. So, the inherent capacity of the experimental soils is very much unsupportive for the growth of crop production but the supplied fertilizer sources is very much supportive to accelerate the growth and yield of rice plants as the source material is very much enriched with nutrient contents.

Finally, it is recommended that the treatment $\mathrm{T}_{4}$ where WCOF was applied @ $1 \mathrm{t}$ ha in combination with 75\% of NPKS @ 80-5-40-10 kg ha, saved 25\% chemical fertilizers and produced substantially higher yield. So, the integrated use of organic and inorganic fertilizer is the need of time for sustaining crop production and soil health as well.

\section{References}

1. Cassman KG, Döbermann AD, Walters DT and Yang H 2003. Meeting cereal demand while protecting natural resources and improving environmental quality. Ann. Rev. Environ. Resour. 28: 315-358.

2. Kirchmann H, Katterer T, Bergstrom L, Borjesson G and Bolinder MA 2016. Flaws and criteria for design and evaluation of comparative organic and conventional cropping systems. Field Crop. Res. 186: 99-106. 
3. Smil V 2000. Feeding the World - A challenge for the 21st Century; MIT Press: Cambridge, MA, USA.

4. Pimentel D 1996. Green revolution agriculture and chemical hazards. Sci. Total. Environ. 188: S86-S98.

5. Tilman D, Cassman KG, Matson PA, Naylor R and Polasky S 2002. Agricultural sustainability and intensive production practices. Nature 418: 671-677.

6. Timsina J 2018. Can organic sources of nutrients increase crop yields to meet global food demand? Journal of Agronomy 8(214): 1-20.

7. Badgley C, Moghtader J, Quintero E, Zakern E, Chappell J, Avilés-Vázquez K, Samulon A and Perfecto I 2007. Organic agriculture and the global food supply. Renew. Agric. Food Syst. 22: 86-108.

8. Seufert V, Ramankutty N and Foley AE 2012. Comparing the yields of organic and conventional agriculture. Nature 485: 229-232.

9. Lal R, Follett F, Stewart BA and Kimble JM 2007. Soil carbon sequestration to mitigate climate change and advance food security. Soil Science 172: 943-956.

10. Ghimire R, Machad S and Rhinhart K 2015. Long-term crop residue and nitrogen management effects on soil profile carbon and nitrogen in wheat-fallow systems. Agronomy Journal 107: 2230-2240.

11. Lal R 2004. The potential of carbon sequestration in soils of south Asia. In:: Conserving Soil and Water for Society: Sharing Solutions. 13th International Soil Conservation Organization Conference, Brisbane. pp. 1-6.

12. Regmi AP, Ladha JK, Pathak H, Pasuquin E, Bueno C, Dawe D, Hobbs PR, Joshy D, Maskey SL and Pandey SP 2002. Yield and soil fertility trends in a 20-year rice-rice-wheat experiment in Nepal. Ame. J. Soil Science Society 66: 857-867.

13. Ladha JK, Dawe D, Pathak H, Padre AT, Yadav RL, Singh B, Singh Y, Singh P, Kundu AL, Sakal R, Ram N, Regmi AP, Gami SK, Bhandari AL, Amin R, Yadav CR, Bhattarai EM, Das S, Aggarwal HP and Gupta RK 2003. How extensive are yield declines in long-term rice-wheat experiments in Asia? Field Crops Research 81: 159-180.

14. Hobbs PR, Sayre K and Gupta R 2008. The role of conservation agriculture in sustainable agriculture. Philosophical Transitions of the Royal Society (B: Biological Sciences). 363: 543-555.

15. Ghimire R, Lamichhane S, Acharya BS, Bista P and Sainju UM 2017. Tillage, crop residue, and nutrient management effects on soil organic carbon in rice-based cropping systems: A review. Elsevier Journal of Integrative Agriculture 16(1): 1-15.

16. Karim Z and Iqbal A 2001. Impact of land degradation in Bangladesh: Changing scenario in agricultural land use. Bangladesh Agricultural Research Council. BARC soils publication no. $42.106 \mathrm{p}$.

17. Rijpma J and Islam MF 2015. Nutrient mining and its effect on crop production and environment in Bangladesh. ftp:/ftp.fao.org/agl. A report prepared for Integrated Soil Fertility and Fertilizer Management Project (SFFP), Bangladesh. $10 \mathrm{p}$.

18. Tan ZX, Lal R and Wiebe KD 2005. Global soil nutrient depletion and yield reduction. Journal of Sustainable Agriculture 26(1): 123-146. 
19. Walkley A and Black IA 1934. An examination of Degtjareff method for determining soil organic matter and a proposed modification of the chromic acid titration method. Soil Sci. 37: 29-38.

20. Gee GW and Bauder JW 1986. In: Klute A (ed.), Methods of soil analysis. Part 1: physical and mineralogical methods. pp. 383-409. $2^{\text {nd }}$ edition. Am. Soc. Agron. Agron no. 9.

21. Fox RL, Olson RA, and Rhoades HF 1964. Evaluating the sulfur status of soils by plants and soil tests. Soil Sci. Soc. Am. Proc. 28: 243-246.

22. Lindsay WL and Norvell WA 1978. Development of DTPA test for zinc, iron, manganese and copper. Soil Sci. Soc. Am. J. 42: 421-428.

23. Schollenberger CJ and Simon RH 1945. Determination of Exchange Capacity and Exchangeable Bases in Soil-Ammonium Acetate Method. Soil Sci. 59: 13-24.

24. Bremner JM and Mulvaney CS 1982. Total nitrogen. In: Page et al. (ed). Methods of Soil Analysis, Part 2. Chemical and Microbiological Properties 9: 595-624. Am. Soc. of Agron. Inc. Madison, Wisconsin.

25. Bray RH and Kurtz LT 1945. Determination of total organic and available phosphorus in soils. Soil Sci. 59: 39-45.

26. FRG 2012. Fertilizer Recommendation Guide, Bangladesh Agricultural Research Council. p. 274.

27. Panaullah GM, Timsina J, Saleque MA, Ishaque M, Pathan ABMBU, Connor DJ, Saha PK, Quayyum MA, Humphreys E and Meisner CA 2006. Nutrient uptake and apparent balances for rice-wheat sequences. III. Potassium. Journal of Plant Nutrition 29(1): 173-187.

28. IRRI 1998. IRRISTAT for Windows, Version 4.1. Biometric unit, International Rice Research Institute. Los Banos, Phillippines.

29. CIMMYT 1988. From agronomic data to farmer recommendations: An economic training manual (Revised Ed.), Mexico. p. 84.

30. Stevenson F 1982. Humus chemistry: Genesis, composition, reactions. John Wiley and Sons Inc. New York. 349 p.

31. Lal R, Kimble JM, Follet RF and Cole CV 1998. The Potential of US cropland to sequester C and mitigate the greenhouse effect. Ann. Arbor. press, Chelsea, MI. pp. 108.

32. Patrick M, Tenywa JS, Ebanyat P, Tenywa MM, Mubiru DN, Basamba TA and Leip A 2013. Soil carbon thresholds and nitrogen management in Tropical agro-ecosystems: Concepts and Prospects. Journal of Sustainable Development 6(12): 31-43.

33. Krull ES, Skjemstad JO and Baldock JA 2004. Functions of Soil organic matter and the effect on soil properties. CSIRO Land and Water, PMB2, Glen Osmond SA 5064. GRDC Project No. CSO 00029. Residue, Soil Organic Carbon and Crop Performance.

34. Sparling GP and Schipper LA 2002. Soil quality at a national scale in New Zealand. Journal of Environmental Quality 31: 1848-1857.

35. Chaplot V and Cooper M 2015. Soil aggregate stability to predict organic carbon outputs from soils. Geoderma. 243: 205-213. 